\title{
Pink skin, urine and effluent fluid after cyanide poisoning
}

Sophie Debord, Gael Bourdin, Alina Stoian, Frédérique Bayle, Véronique Leray, Jean-Christophe Richard and Claude Guérin*

*Correspondence: claude.guerin@chu-lyon.fr

Medical Intensive Care and Respiratory Support Hospital, the Croix-Rousse, Lyon, France.

\begin{abstract}
We are reporting a fatal case of cyanide intoxication due to voluntary ingestion treated by hydroxycobalamin as antidote. Twelve hours after ICU admission abnormal pink colored skin and urines were observed. The effluent fluid removed during the continuous veno-venous hemofiltration treatment also exhibited pink colour. Even though pink coloured skin and urines is a well-known side-effect of the hydroxycobalamin use as an antidote for cyanide, such an abnormal colour of the effluent fluid has not been previously reported. Contrary to what has been described with the haemodialysis machines whose functioning may be impaired by hydroxycobalamin, the device used to perform continuous renal replacement therapy has worked properly in present case. Therefore, continuous renal replacement therapy should be the first choice method if needed in this setting.
\end{abstract}

Keywords: Cyanide intoxication, hydroxycobalamine, coloured urines, pink skin, continuous hemofiltration, coloured effluent fluid

\section{Introduction}

Severe cyanide intoxication includes cardiac arrhythmias, convulsions and coma occurring shortly after toxic exposure. Indeed, cyanide very rapidly penetrates the cells and binds to the cytochrome c oxidase, resulting in inhibition of mitochondrial respiration and ATP formation. This promotes diffuse tissue hypoxia, metabolic acidosis and increased plasma lactate [1]. Management of severe cyanide intoxication includes: 1) supportive therapy with pure oxygen administration, invasive mechanical ventilation if comatose state or status epilepticus, cardiovascular support and bicarbonate infusion, and 2) antidotes, which should be administered immediately to reverse the combination of cyanide with the cytochrome oxidase. Hydroxycobalamin is an effective antidote as it binds cyanide without the concomitant formation of methemoglobin. It acts rapidly and may improve hemodynamic status. Its side effects are urticaria and red coloured skin and urines, but anaphylactic shock has been reported with hydroxycobalamin use [2]. In the daily civil life, acute cyanide intoxication occurs after smoke inhalation from fire accidents and very rarely from voluntary ingestion [3]. We are reporting the case of a voluntary ingestion of cyanide treated with hydroxycobalamin, in which skin and urines, and also effluent fluid removed during the continuous veno-venous hemofiltration (CVVH) treatment were pink colored. This colour has been attributed to the use of Hydroxycobalamin.

\section{Case Report}

A 48-year old male technician in chemical industry, with a past history of psychiatric disorder, committed suicide at his workplace by voluntary ingesting one spoon of cyanide sodium on $10^{\text {th }}$ January 2013 at $2.00 \mathrm{pm}$. Five minutes later, he presented generalized seizures. The occupational physician called immediately by the fellows of the patient administered $2.5 \mathrm{~g}$
Hydroxycobalamin $\left(\right.$ Cyanokit $\left.^{\circ}\right)$ subcutaneously in the left arm. The pre-hospital emergency team (SAMU 69) starts operating at $2.40 \mathrm{pm}$. The patient was immediately intubated and was receiving an additional $5 \mathrm{~g}$ Hydroxycobalamin intravenously. Due to sinusal bradycardia and hypotension, he was given epinephrine as a $1 \mathrm{mg}$ intravenous bolus followed by a $4 \mathrm{mg} \cdot \mathrm{h}^{-1}$ continuous intravenous infusion and $2000 \mathrm{ml}$ isotonic saline intravenous infusion.

At time of ICU admission (3.59 pm), the Glasgow Coma Scale was 3 and both pupils were not reactive to the light stimulation. The following clinical findings were noted: mean arterial pressure $63 \mathrm{~mm} \mathrm{Hg}$, heart rate with atrial fibrillation and ventricular rate 133. $\mathrm{min}^{-1}$, mottled skin, anuria, cardiac index $2.7 \mathrm{~L} \cdot \mathrm{min}^{-1} \cdot \mathrm{m}^{-2}$. The skin of both arms was pink colored (Figures $1 \mathrm{~A}$ and $1 \mathrm{~B}$ ). Blood chemistry disclosed the followings: $\mathrm{pH} 6.89, \mathrm{PaCO} 2$ $34 \mathrm{mmHg}, \mathrm{PaO} 2494 \mathrm{mmHg}$ under $\mathrm{F}_{1} \mathrm{O}_{2}$ 1, arterial lactate 25

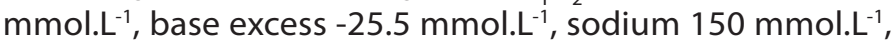
potassium $3.5 \mathrm{mmol}^{-\mathrm{L}^{-1}}$, bicarbonate $6.5 \mathrm{mmol}^{-1}$, creatinine 104 mcmol.L-1, total calcium 2.04 mmol.L-1, phosphore $3.14 \mathrm{mmol}^{-L^{-1}}$, total magnesium $1.96 \mathrm{mmol}^{-1}$. Blood coagulation tests were as follows: International Normalized Ratio 1.5, Prothrombin time $54 \%$, platelets count 94 giga. L $^{-1}$, partial thromboplastin time 2.4 times the control, plasma fibrinogen $2{\mathrm{~g} . \mathrm{L}^{-1}}^{-}$, fibrin degradation products $40 \mathrm{mcg}^{-\mathrm{ml}^{-1}}$. The first Chest-X-ray (4.11 pm) showed bilateral infiltrates in both lung lower lobes. A further $5 \mathrm{~g}$ dose of Hydroxycobalamin was given intravenously a few minutes after ICU admission. Continuous intravenous sedation (midazolam $0.07 \mathrm{mg} \mathrm{Kg}^{-1} \cdot \mathrm{h}^{-1}$ ) and analgesia (morphine chlorydrate $\left.0.07 \mathrm{mg} \cdot \mathrm{Kg}^{-1} \cdot \mathrm{h}^{-1}\right)$, together with neuromuscular blockade (cisatracurium $0.18 \mathrm{mg} \cdot \mathrm{Kg}^{-1} \cdot \mathrm{h}^{-1}$ ), were started. Antibiotics including gentamicin, ceftriaxone and metronidazole were given after having sampled blood and lung (fiberoptic broncho-alveolar lavage) for microbiological assessment. 


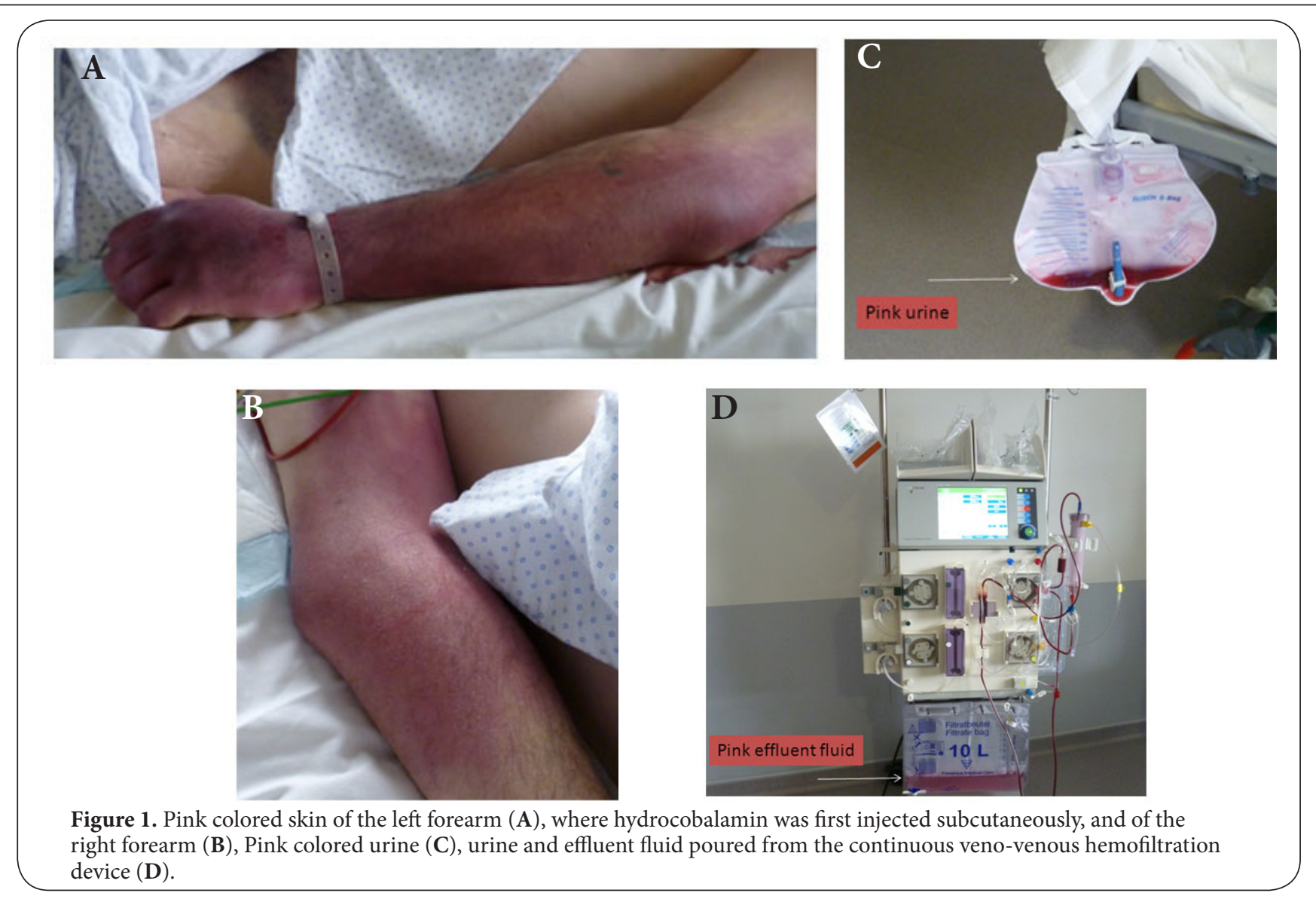

CVVH was started one hour after ICU admission. Pre- and post-dilution substitution fluid was added volume for volume with ultrafiltration loss at a $95 \mathrm{ml} . \mathrm{kg} \cdot \mathrm{h}^{-1}$ rate. Within the next 6 hours, the patient received intravenously $5,500 \mathrm{ml}$ Ringer lactate and $250 \mathrm{ml}$ Bicarbonate $4.2 \%$. With the recovery of diuresis twelve hours after ICU admission, the urines were pink colored (Figure 1C). The effluent fluid removed by the $\mathrm{CVVH}$ device was also pink colored (Figure 1D). The functioning of the CVVH device was not impaired by this discoloration. The broncho-alveolar lavage done on ICU admission grew $10^{3}$ Units Forming Colony (UFC) Streptococcus hemolyticus, $10^{5}$ UFC Methicillin-Sensitive Staphylococcus aureus, $10^{5}$ UFC Haffnia alvei and $10^{5}$ UFC Stomatococcus. Blood samples were sterile.

Arterial lactate went to normal value $\left(<2 \mathrm{mmol}^{-\mathrm{L}^{-1}}\right) 24$ hours after admission but plasma $\mathrm{pH}$ and base excess needed a further 36-hour to normalize. However, the patient could not be weaned from the vasoactive support and required CVVH for persistent oliguria. On day 5, abdominal CT scan was indicated for increased arterial lactate and showed right colon ischemia. The patient underwent laparotomy, which confirmed ischemic perforation in the right colon with peritonitis. Right colectomy was performed. The surgical procedure was followed by immediate hemodynamic improvement. The patient remained in comatose state even though sedation had been stopped for several days. Brain Magnetic Resonance Imaging was performed on day 12 of the ICU stay and showed hemorrhagic necrosis of the central grey nuclei with widespread small hemorrhagic foci involving temporal and frontal brain regions. Treatment was withdrawn in accordance with patient's family. The patient eventually died 19 days after ICU admission.

\section{Discussion}

Cyanide poisoning by suicide is uncommon as compared to that occurring after smoke inhalation [4]. Therefore, the clinicians should be aware of this specific setting for cyanide poisoning in order to administer the antidote without any delay after making clinical suspicion. In our case, the patient committed suicide at his workplace, which was a chemical plant, with a free access to cyanide. Therefore, the suspicion of cyanide poisoning was made easier. Indeed, the company doctor, who was called by the fellow workers of the patient, at time he rushed at the scene of the casualty, was completely aware of what had happened and, hence administered the antidote immediately. In the present case, in spite of an early diagnosis of cyanide poisoning and early antidote administration, the outcome was fatal. In previous reports on suicide attempts by cyanide ingestion some patients may survive [5]. 
Hydroxycobalamin is a key component of the management [6] and must be immediately administered once the diagnosis of cyanide poisoning is suspected. It should be mentioned again that the diagnosis is very difficult in case of smoke inhalation. A group of European experts has recently acknowledged hydroxocobalamin as a valid empiric treatment for fire smoke victims [7]. For cyanide salt intoxication, as it occurred in present case, Thompson et al., [8] reviewed the available pharmacological data on hydroxycobalamin and concluded that it was an effective antidote.

Pink colored skin and urine is a common and transient side-effect of hydroxycobalamin use [9-11]. In present case the skin coloration did not look like urticarial and might have resulted from other causes, like hematoma as some blood coagulation disorders were present on admission, or infection. This latter hypothesis seemed unlikely as blood cultures were sterile.

In the present case, we furthermore observed that the effluent fluid during high volume CVVH treatment was also pink colored, a finding that was not previously reported. The colour of the fluid effluent was not associated with any harmful effect. However, it is important to rule out other reasons for pink colored effluent fluid as hemolysis or to rule out filter leaks. Furthermore, it should be noted that the appropriate functioning of the CVVH machine was not impaired by hydroxycobalamin, contrary to what has been reported for the haemodialysis machine [12-14]. In particular hydroxycobalamin can interfere with the blood leak detection device in some haemodialysis machines [12-14]. It is not the mode of renal replacement therapy, namely conventional intermittent haemodialysis or CVVH, that is challenged but the machine used to deliver the mode. Therefore, the use of CVVH should be recommended as the first choice technique to perform renal replacement therapy efficiently in this setting according to the above considerations.

\section{Competing interests}

The author's declare that they have no competing interests.

Authors' contributions

\begin{tabular}{|l|c|c|c|c|c|c|c|}
\hline Authors' contributions & SD & GB & AS & FB & VL & JCR & CG \\
\hline Research concept and design & -- & -- & -- & -- & -- & $\sqrt{ }$ & $\sqrt{ }$ \\
\hline $\begin{array}{l}\text { Collection and/or assembly } \\
\text { of data }\end{array}$ & $\sqrt{ }$ & $\sqrt{ }$ & -- & -- & -- & - & $\sqrt{ }$ \\
\hline Data analysis and interpretation & -- & -- & -- & -- & -- & -- & $\sqrt{ }$ \\
\hline Writing the article & -- & -- & -- & -- & -- & -- & $\sqrt{ }$ \\
\hline Critical revision of the article & $\sqrt{ }$ & -- & -- & -- & -- & $\sqrt{ }$ & $\sqrt{ }$ \\
\hline Final approval of article & $\sqrt{ }$ & $\sqrt{ }$ & $\sqrt{ }$ & $\sqrt{ }$ & $\sqrt{ }$ & $\sqrt{ }$ & $\sqrt{ }$ \\
\hline Statistical analysis & -- & -- & -- & -- & -- & -- & $\sqrt{ }$ \\
\hline
\end{tabular}

\section{Publication history}

Senior Editors: Eric Murillo Rodriguez, Anahuac Mayab University, Mexico.

Naval K. Vikram, All India Institute of Medical Sciences, India.
Received: 09-Jul-2013 Revised: 12-Aug-2013

Re-Revised: 21-Aug-2013 Accepted: 02-Sep-2013

Published: 16-Sep-2013

\section{References}

1. Baud FJ, Borron SW, Megarbane B, Trout H, Lapostolle F, Vicaut E, Debray $\mathrm{M}$ and Bismuth $\mathrm{C}$. Value of lactic acidosis in the assessment of the severity of acute cyanide poisoning. Crit Care Med. 2002; 30:2044-50. I Article | PubMed

2. Megarbane B, Delahaye A, Goldgran-Toledano D and Baud FJ. Antidotal treatment of cyanide poisoning. J Chin Med Assoc. 2003; 66:193-203. I PubMed

3. Lawson-Smith $P$, Jansen EC and Hyldegaard O. Cyanide intoxication as part of smoke inhalation--a review on diagnosis and treatment from the emergency perspective. Scand J Trauma Resusc Emerg Med. 2011; 19:14. | Article | PubMed Abstract | PubMed FullText

4. Fortin JL, Waroux S, Giocanti JP, Capellier G, Ruttimann M and Kowalski $\mathrm{JJ}$. Hydroxocobalamin for poisoning caused by ingestion of potassium cyanide: a case study. J Emerg Med. 2010; 39:320-4. | Article | PubMed

5. Coentrao $L$ and Moura $D$. Acute cyanide poisoning among jewelry and textile industry workers. Am J Emerg Med. 2011; 29:78-81. | Article | PubMed

6. Borron SW and Baud FJ. Antidotes for acute cyanide poisoning. Curr Pharm Biotechnol. 2012; 13:1940-8. | Article | PubMed

7. Anseeuw K, Delvau N, Burillo-Putze G, De laco F, Geldner G, Holmstrom $P$, Lambert $Y$ and Sabbe $M$. Cyanide poisoning by fire smoke inhalation: a European expert consensus. Eur J Emerg Med. 2013; 20:2-9. | Article I PubMed

8. Thompson JP and Marrs TC. Hydroxocobalamin in cyanide poisoning. Clin Toxicol (Phila). 2012; 50:875-85. | Article | PubMed

9. Brunel C, Widmer C, Augsburger M, Dussy F and Fracasso T. Antidote treatment for cyanide poisoning with hydroxocobalamin causes bright pink discolouration and chemical-analytical interferences. Forensic Sci Int. 2012; 223:e10-2. | Article | PubMed

10. Cescon DW and Juurlink DN. Discoloration of skin and urine after treatment with hydroxocobalamin for cyanide poisoning. CMAJ. 2009; 180:251. | Article | PubMed Abstract | PubMed FullText

11. Hon KL and Cheung KL. Pink toes and red urine: what is this poison? Hong Kong Med J. 2010; 16:411-2. I PubMed

12. Sutter ME, Clarke ME, Cobb J, Daubert GP, Rathore VS, Aston LS, Poppenga RH, Ford JB, Owen KP and Albertson TE. Blood leak alarm interference by hydoxocobalamin is hemodialysis machine dependent. Clin Toxicol (Phila). 2012; 50:892-5. | Article | PubMed

13. Sutter M, Tereshchenko N, Rafii R and Daubert GP. Hemodialysis complications of hydroxocobalamin: a case report. J Med Toxicol. 2010; 6:165-7. | Article | PubMed Abstract | PubMed FullText

14. Stellpflug SJ, Gardner RL, Leroy JM, Ellsworth $\mathrm{H}$ and Zwank MD. Hydroxocobalamin hinders hemodialysis. Am J Kidney Dis. 2013; 62:395. | Article | PubMed

\section{Citation:}

Debord S, Bourdin G, Stoian A, Bayle F, Leray V, Richard $\mathrm{J}-\mathrm{C}$ and Guerin C. Pink skin, urine and effluent fluid after cyanide poisoning. J Med Disord. 2013; 1:3.

http://dx.doi.org/10.7243/2053-3659-1-3 